International Electronic Scientific Journal "Science Online" http://nauka-online.com/

Юридичні науки

УДК 341

\title{
Шаргородська Ірина Віталіївна
} компанія «System Capital»; студентка кафедри Міжнародного приватного права Інституту післядипломної освіти Киїського національного університету імені Тараса Шевченка

\section{ДОСВІД ОРГАНІЗАЦІЇ ФЕДЕРАЛЬНИХ ПАРЛАМЕНТСЬКИХ} ВИБОРІВ У НІМЕЧЧИНІ ДЛЯ ПОКРАЩЕННЯ ОРГАНІЗАЦІї ВИБОРІВ ДО ПАРЛАМЕНТУ УКРАЇНИ

ОПЫТ ОРГАНИЗАЦИИ ФЕДЕРАЛЬНЫХ ПАРЛАМЕНТСКИХ ВЫБОРОВ В ГЕРМАНИИ ДЛЯ УЛУЧШЕНИЯ ОРГАНИЗАЦИИ ВЫБОРОВ В ПАРЛАМЕНТ УКРАИНЫ EXPERIENCE ON ORGANIZATION THE FEDERAL PARLIAMENTARY ELECTIONS IN GERMANY FOR IMPROVEMENT ORGANIZATION ELECTIONS TO THE PARLIAMENT OF UKRAINE

Анотація. Стаття присвячена дослідженню особливостей організації парламентських виборів в Украӥні та Німеччині. Вивчається проведення й правова природа організачії виборів. Аналізується співвідношення спільних та відмінних рис між ними з метою виявлення та виокремлення передумов для покращення організації виборів до парламенту Украӥни.

Ключові слова: парламентаризм, Бундестаг, Бундесрат, мажоритарна, змішана, пропориійна виборчі системи. 
Аннотация. Статья посвящена исследованию особенностей организации парламентских выборов в Украине и Германии. Изучается проведения и правовая природа организащии выюоров. Анализируется соотномение общих и отличительных черт между ними с изелью выявления и выделения предпосылок для улучшения организации выборов в парламент Украины.

Ключевые слова: парламентаризм, Бундестаг, Бундесрат, мажоритарная, смешанная, пропорииональная избирательные системы.

Summary. The article is devoted to the study of the peculiarities of organizing parliamentary elections in Ukraine and Germany. It is also studied the legal nature of the organization of elections. The correlation between common and distinctive features among them is analyzed in order to identify and distinguish the preconditions for improving the organization of elections to the Parliament of Ukraine.

Key words: parliamentarism, Bundestag, Bundesrat, majoritarian, mixed, proportional electoral systems.

Постановка проблеми. Удосконалення принципів функціонування парламентської системи управління є однією з ключових проблем сьогодення для багатьох держав. Вивчення цього питання слід розглядати із різних аспектів аналізу, зокрема інституційно-управлінського, нормативно-правового та соціально-економічного підходів. Теоретична актуальність теми дослідження полягає у аналізі правових основ побудови та розвитку парламентської системи Німеччини, їх історичних витоків для всебічного виявлення та розгляду характеру конкретних правових явищ. Водночас практична значущість iï аналізу полягає у дослідженні умов функціонування 
та розвитку Бундестагу Німеччини як центрального елементу демократії у виборних органах країни. Зазначене має значення покращення організації виборів до парламенту України й захисту інтересів найменш захищених сил у парламенті нашої держави.

Аналіз останніх досліджень і публікацій. Проблему формування Бундестагу ФРН розглядали німецькі вчені Klaus-J. Holzapfel й Andrea GertigHadaschik, які вважали доцільним закріплення в парламентському праві ФРН однакового права на переставлення своїх інтересів між проурядовими та опозиційними силами. Водночас українські вчені О.В. Філонов та С.М. Пашков вважають, що такий механізм представлення сил $є$ породжує неузгодженість внутрішньої політики.

Формулювання цілей статті (постановка завдання). Мета дослідження полягає в тому, щоб системно і комплексно дослідити питання особливостей організації парламентських виборів в Україні та Німеччині,

Для досягнення зазначеної мети сформовано такі завдання:

- розглянути особливості організації парламентських виборів до ФРН;

- визначити спільні та відмінні риси у проведенні виборів до парламенту ФРН та України;

- проаналізувати переваги та недоліки імплементації німецького виборчого процесу для України.

Виклад основного матеріалу. На сьогодні характерним для організації діяльності та структури парламенту в Німеччині $є$ те, що законодавча влада як і раніше сконцентрована на федеральному рівні у двох палатах - Бундестагу та Бундесрату, а на рівні земель - у ландтагах. Так після формування законодавчих ініціатив на рівні міністерств вони надсилаються на обговорення й прийняття до верхньої палати парламенту ФРН - Бундестагу. Після рішення верхньої палати законопроект направляється на обговорення й можливе 
доповнення до Бундесрату. Остання версію документа із усіма змінами й доповненнями приймає для голосування Бундестаг.

Згідно з Конституцією ФРН Бундестаг - це вищий орган влади, який здійснює представництво німецького народу та має значні законодавчі повноваження. У ст.20 “Основного закону” ФРН зазначено: “Вся державна влада йде від народу. Вона здійснюється народом шляхом виборів, голосування та через особливі законодавчі, виконавчі та судові органи ...”. У відповідності зі ст. 28 (ч.2) “Основного закону”, народ, повинен мати виборне представництво у федеральних землях Німеччини, а також в округах $\mathrm{i}$ муніципалітетах. Основоположним при цьому $\epsilon$ зафіксований в ст.33 “Основного закону” принцип про рівність всіх німців в їхніх громадянських правах та обов'язках [11].

Процедура волевиявлення до парламенту ФРН майже не відрізняється від українських реалій, однак є і свої відмінності. Так, з 1957 року дозволяється голосування поштою (з 2008 року навіть без обгрунтування необхідності). Такий виборець має заздалегідь надіслати запит (поштою чи онлайн) на вислання йому виборчого бюлетеню, який він у заповненому вигляді i запечатаному конверті він повинен відправити поштою або особисто віддати до дільниці, але не пізніше, ніж іiі закриття безпосередньо у день голосування. На останніх виборах до бундестагу поштовим правом скористалися 21,4\% виборців. Існують також й ініціативи щодо впровадження онлайн-голосування, однак на практиці вводити цей метод поки що не поспішають [5].

Типовим для передвиборчої кампанії як у Німеччині так в Україні є іiі персоніфікація. Партії заздалегідь визначаються зі своїм головним кандидатом, від особистої популярності якого серед населення напряму залежатиме успіх партії на виборах. Партія-переможець отримує право на формування уряду на чолі зі своїм головним кандидатом. У ФРН діє також 5\% 
прохідний бар'єр для пропорційної частини виборчої системи та аналогічний ценз у вигляді 3-х округів для мажоритарників. На відміну від української зміманої, а точніше, паралельної виборчої системи, в якій дві рівних половини парламенту обирається за різними системами, німецька - взаємозв'язана. Так, якщо партія, яка висунула кандидатів по пропорційній частині набере 3 мандати в округах, то, за умови низького результату по списку, вона отримає додаткові мандати у відсотковій пропорції до загальної кількості депутатів бундестагу. Якщо ж навпаки, подолає 5\% бар'єр, але не візьме перемогу в 3-х округах, то отримає лише ту частину мандатів, яка припадає до цієї пропорції.

Розглянемо у вигляді таблиці спільні та відмінні риси організації виборчого процесу до парламенту ФРН та України, див. табл. 1.

Таблиия 1

\section{Спільні та відмінні риси між парламентом ФРН та Украӥни у проведенні}

\section{виборів}

\begin{tabular}{|l|l|}
\hline Спільні риси & Відмінні риси \\
\hline $\begin{array}{l}\text { Більший вплив на результати голосування } \\
\text { населення }\end{array}$ & $\begin{array}{l}\text { Постійний контроль процесу виборів у } \\
\text { ФРН з боку наглядачів СС }\end{array}$ \\
\hline Перевага голосів літніх людей & $\begin{array}{l}\text { Відсутність публікації у ФРН результатів } \\
\text { екзит-полів за 2-3 дні до голосування }\end{array}$ \\
\hline Побудова коаліцій & $\begin{array}{l}\text { Представлення більшості партій ФРН не у } \\
\text { всіх федеральних землях }\end{array}$ \\
\hline $\begin{array}{l}\text { Збереження впливу на результати } \\
\text { голосування політичного фактора }\end{array}$ & \begin{tabular}{l} 
Незначні витрати на вибори \\
\hline Наявні інформаційні ризики
\end{tabular} \\
\hline $\begin{array}{l}\text { Віддача голосу за замельний список в } \\
\text { цілому, а не окремих кандидатів }\end{array}$ & $\begin{array}{l}\text { Відсутність впливу ФРН на формування } \\
\text { кандидатур депутатів }\end{array}$ \\
\hline Наявний молодий склад депутатів & $\begin{array}{l}\text { Можливість проходження до Бундестагу за } \\
\text { надлишковим мандатом (невигідно } \\
\text { опозиції) }\end{array}$ \\
\hline
\end{tabular}

Крім того, серед інших відмінних рис є те, що Німеччина відома своєю високою політичною культурою і демократичними традиціями, а також 
суворістю законів, тому партії, як правило, не витрачають час і гроші на «чорний» піар й пошуком компромату на опонентів.

Крім того у законодавстві ФРН якомога повніше передбачено різні життєві ситуації виборців. Так, наприклад, у разі раптової хвороби виборця він може звернутися з проханням проголосувати за посвідченням до 15 годин у день виборів. При цьому з заявою на отримання посвідчення виборець може звернутися особисто або через іншу людину у будь-якій формі: письмово, телеграмою, факсом, електронною поштою та іншими засобами електронної передачі даних, які можуть бути зареєстрованими [6].

Враховуючи викладене вище, можна дійти висновку, що німецькій виборчій системі вдалося скорегувати такий суттєвий недолік пропорційної системи голосування, як відсутність зв'язку представників зі своїми виборцями, шляхом застосування:

- персоніфікованих виборів половини парламенту в одномандатних округах;

- зв'язаного розподілу мандатів між пропорційною і мажоритарною частинами електоральної формули;

- пропорційного голосування за земельними (регіональними) списками;

- альтернативного прохідного бар'єра, який дозволяє пройти до парламенту партіями, які не отримали 5\% голосів, але перемогли у трьох виборчих округах.

Систематизуємо у вигляді таблиці переваги та недоліки імплементації німецького виборчого процесу для України, див. табл. 2.

Таким чином, серед основних недоліків використання німецького законодавчого досвіду слугує відсутність можливостей за власної ініціативи впливу Бундестагу ФРН на проведення референдуму серед населення. Крім того, серед інших ризиків є можливість нав'язування ідеології найбільш 
впливових політичних партій, що тримали додаткові мандати у густонаселених регіонах щодо прийняття законодавчих ініціатив.

Табличя 2

\section{Аналіз переваг та недоліків імплементації німецького виборчого процесу}

для України

\begin{tabular}{|l|l|}
\hline Переваги & Недоліки \\
\hline $\begin{array}{l}\text { Спрощена й диверсифікована система } \\
\text { голосування }\end{array}$ & $\begin{array}{l}\text { Відсутність постійного зв’язку } \\
\text { представників зі своїми виборцями }\end{array}$ \\
\hline $\begin{array}{l}\text { Зв’язаність розподілу мандатів між } \\
\text { пропорційною та мажоритарною } \\
\text { системами }\end{array}$ & $\begin{array}{l}\text { Особливий закон не передбачає } \\
\text { одноособового рішення Бундестагу на } \\
\text { проведення референдуму (ВРу має) }\end{array}$ \\
\hline $\begin{array}{l}\text { Альтернативний прохідний бар'єр для } \\
\text { партій, які набрали менше 5\% }\end{array}$ & $\begin{array}{l}\text { Можливість посилення впливових партій } \\
\text { на результати виборів }\end{array}$ \\
\hline $\begin{array}{l}\text { Розгляд скарг виборців протягом двох } \\
\text { місяців після завершення голосування }\end{array}$ & $\begin{array}{l}\text { Поштове голосування може підпадати під } \\
\text { деструктивні кібер-атаки }\end{array}$ \\
\hline $\begin{array}{l}\text { Відкритість згідно ст.42 Основного закону } \\
\text { проведення засідань }\end{array}$ & $\begin{array}{l}\text { Триваліший законодавчий процес з огляду } \\
\text { на його обговорення на двох рівнях }\end{array}$ \\
\hline $\begin{array}{l}\text { Можлива зміна персонального складу } \\
\text { депутатів після завершення виборів }\end{array}$ & $\begin{array}{l}\text { Згідно ст.67 Основного закону } \\
\text { відсторонення фед. Канцлера від } \\
\text { зобов'язань можливе лише після виборів } \\
\text { іншої особи на цю посаду }\end{array}$ \\
\hline
\end{tabular}

У свою чергу, перевагою використання німецького досвіду є розвиток демократичного підходу до проведення виборів населенням країни в рамках врахування інтересів усіх соціальних груп та формуванні зустрічних позицій для осіб із обмеженими можливостями. Крім того серед переваг на законодавчому рівні є проведення відкритих засідань парламенту й можливість заміни кандидатури депутатів після завершення виборів.

У процедурі обрання кандидатів до Бундестагу Німеччина не володіє однією 3 найбільш передових практик в інструментарії голосування та не використовує, до прикладу, голосування через мережу Інтернет. Два офіційні аргументи не дають переступити цю межу німцям: загроза розголошення таємниці голосування через втручання в електронні системи IT-зловмисників 
та ненадійність результатів підрахунку, які, знову ж таки, завдяки кібератакам можуть бути скореговані. Однак число тих, хто вважає за краще проголосувати поштою, росте від виборів до виборів.

Висновки і перспективи подальших досліджень. Таким чином, історичний досвід розвитку парламентаризму Німеччини $\epsilon$ найбільш переконливим прикладом успішного переходу від авторитарнотерористичного режиму до стійкої демократії на основі поєднання ефективної ринкової економіки, державного регулювання і соціальної справедливості в інтересах політичної стабільності. Найбільшими перевагами використання німецького досвіду є врахування під час виборів інтересів усіх соціальних груп та на законодавчому рівні проведення відкритих засідань парламенту й можливість заміни кандидатури депутатів після завершення виборів.

Отже, таке дослідження умов функціонування та розвитку Бундестагу Німеччини як центрального елементу демократії у виборних органах ФРН створює засади із покращення правових й соціальних аспектів організації виборів до парламенту України й захисту інтересів найменш захищених сил у парламенті нашої держави.

\section{Література}

1. Закон України "Про внутрішню та зовнішню політику" // Відомості Верховної Ради України, 2008. № 50. С. 384.

2. Бесчасний В. М., Філонов О. В., Суботін В. М. та ін. "Конституційне право зарубіжних країн": навч. пос. К. : Знання, 2008. 467 с.

3. Короткий курс 3 конституційного права зарубіжних країн: навч. Посібник / І. Ш. Резепов. - 3 - е изд., стер. - М.: Видавництво В “Окей книгаВ", 2010.93 с. 
4. Клайн Г., ЦЕЕ В. Бундестаг // Державне право Німеччини. Т. 1. М.: ІГПАН, 1994. 152 c.

5. Чиркин В.С. Конституційне право зарубіжних країн: Підручник. - 2-ге вид., Перероб. і доп. - К., 2001. 439 с.

6. Якушев А.В. Конституційне право зарубіжних країн. Загальна частина. Особлива частина (50 держав). - М.: А-Пріор, 2007. 121 с.

7. Klaus-J. Holzapfel й Andrea Gertig-Hadaschik. Deutscher Bundestag / 18. Wahlperiode - Stand: 9.Dezember 2016. S319.

8. Конституційне право зарубіжних країн: навч. посібник / В. О. Ріяка та ін. К.: Юрінком інтер, 2002. 512 с.

9. Мишин А. А. Конституционное право зарубежных стран: Учебник. М.: Белые Альвы, 2006. 400 с.

10.Нижник Н., Дуда А. Конституційно-правова основа діяльності та повноважень Уряду України // Вісник Української Академії державного управління при Президентові України. 2006. №1. С. 60-65.

11.Офіційна веб-сторінка Бундестагу. URL: www.bundestag.de

\section{Referenses}

1. The Law of Ukraine "On Internal and External Policies" // Bulletin of the Verkhovna Rada of Ukraine, 2008. No. 50. P. 384

2. Timeless V.M., Filonov O.V., Subotin V.M. and others. "Constitutional Law of Foreign Countries": Teaching. K.: Knowledge, 2008. 467 p.

3. Short course on the constitutional law of foreign countries: taught. manual / I. Sh. Rezepov - 3rd ed., Ster. M .: Publishing House in "Okey Book", 2010. 93 p.

4. Kline G., CEE V. Bundestag // State law of Germany. T. 1. M .: IGPAN, 1994. $152 \mathrm{p}$. 
5. Chirkin V. E. Constitutional Law of Foreign Countries: Textbook. - 2nd form., Process. and add. K., 2001. 439 p.

6. Yakushev A. V. Constitutional law of foreign countries. General part Special part (50 states). M .: A-Prior, 2007. $121 \mathrm{p}$.

7. Klaus-J Holzapfel and Andrea Gertig-Hadaschik. Deutscher Bundestag / 18. Wahlperiode - Stand: December 9, 2016. S. 319.

8. Constitutional Law of Foreign Countries: Teach. manual / V.O. Riyaka et al. K.: Yurinkom inter, 2002. $512 \mathrm{p}$.

9. Mishin A.A. Constitutional Law of Foreign Countries: Textbook. Moscow: White Alves, 2006. $400 \mathrm{p}$.

10.Nyzhnik N., Duda A. Constitutional and legal basis of the activity and authority of the Government of Ukraine // Bulletin of the Ukrainian Academy of Public Administration under the President of Ukraine. 2006. №1. PP. 6065.

11.Bundestag official website. URL: www.bundestag.de 